\title{
最近の歯学
}

\section{4. 口腔生理}

\section{In vitro 下顎一神経標本}

東京医科歯科大学歯学部口腔生理学教室 戸田一雄

痛みの受容器である侵害受容器には, 種々のサブタ イプが存在することが, 最近の研究から明らかにされ ている。それらの報告の多くは, 皮虐, 筋でのもので あり, 口腔内の侵害受容器をサブタイプに分類した研 究は存在しなかった。その最大の理由として, 口腔内 は, 定量的な刺激を与えにくい解剖学的構造をしてい ることが挙げられる。侵害受容器をサブタイプに分類 するには, 少なくとも 3 種類の定量的刺激を受容野に 与えることが必要である。すなわち, 機械刺激, 熱刺 激, 化学刺激である。従来の方法では, 口腔内にこれ らの刺激を定量的に与えることは，非常に困難であっ たために, 口腔内の侵害受容器をサブタイプに分類す ることに成功しなかった。

筆者の教室では, 口腔内の侵害受容器の生理学的特 性を調べるために in vitro 下顎一神経標本を開発して 研究を進めている1)。この標本では, 下肢皮膚侵害受容 器の研究のために, Erlangen 大学の Reeh 教授グルー プが報告している皮膚一神経標本と類似の手法を用い ている2)。われわれの下顎一神経標本ではラットの片 側下顎を下歯槽神経と舌神経とを一体として取り出 す。標本が皮䖉一神経標本に比べて大きいため, 標本

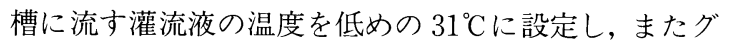
ルコース濃度を $20 \mathrm{mM}$ にしたここことにより, 標本 を約 5 時間にわたり，生存させることができた。また， 記録法として, タングステン微小電極を用いた微小神 経電図法を応用して，ユニット活動を記録した。この 記録法は, 単一神経線維に分離して, 鈎電極にて記録 する従来の方法に比べ簡単である。

さて，この標本を用いた記録例を図 1 に示す3)。この 例は, 舌側口腔粘膜に分布するC-ポリモーダル侵害受 容器の例である。このユニットは，機械刺激(a), 熱刺 激(b)，化学刺激(c)すべてに応答している。興味深いこ とに，C線維に支配されるロ腔粘膜の侵害受容器はポ リモーダル侵害受容器のみであり, 皮膚に存在するよ うな, C-高閾值侵害受容器や C-機械熱侵害受容器は 見つからなかった。このことは，粘膜と皮膚とでは，
侵害受容器のサブタイプの分布が異なっていることを 示している。

現在，当教室では，下顎一神経標本を用いて，歯根 膜，歯髄，顎関節などの機械受容器および侵害受容器 の特性を解析しており, 将来口腔領域の体性感覚機構 がより詳細に明らかになることが期待される。

\section{文献}

1) Toda, K., Ishii, N. and Nakamura, Y.: An in vitro jaw-nerve preparation for oral sensory study in the rat. J. Neurosci. Methods $61: 85^{-}$ 90, 1995.

2) Reeh, P. W. : Sensory receptors in mammalian skin in an in vitro preparation. Neurosci. Lett. $66: 141-146,1986$

3) Toda, K., Ishii, N. and Nakamura, Y. : Characteristics of mucosal nociceptors in the rat oral cavity ; an in vitro study. Neurosci. Lett. 228 : 95-98, 1997.

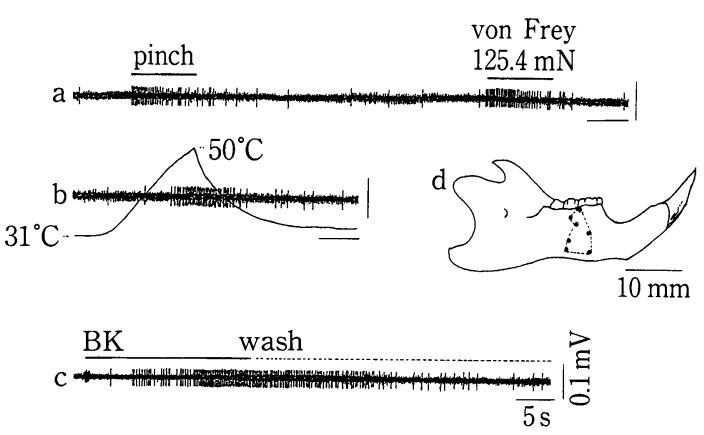

図 1 舌側口腔粘膜に分布するC-ポリモーダル侵害 受容器

a：Pinch およびvon Freyによる機械刺激応 答, $\mathrm{b} ： 50^{\circ} \mathrm{C}$ の熱刺激応答, $\mathrm{c}$ ：ブラジキニンによ る化学刺激応答, $d$ ：このユニットの受容野 